\title{
Development of Fly ash-GGBS based Self Compacting Geopolymer Concrete: a Review
}

\author{
A.Vinothkumar ${ }^{1 *}$, M.Kalaivani ${ }^{2}$ and P.Easwaran ${ }^{2}$ \\ ${ }^{1}$ PG Student, K.S.Rangasamy College of Technology, Tiruchengode-637215 Tamil Nadu, India. \\ ${ }^{2}$ Assistant Professor, K.S.Rangasamy College of Technology, Tiruchengode-637215 Tamil Nadu, India. \\ *Corresponding author E-Mail ID: vinothkumar23071995@gmail.com \\ Doi: https://doi.org/10.34256/irjmtcon49
}

\begin{abstract}
Concrete is the most used construction material in construction Industries all over the world. The main binding ingredient of concrete that is ordinary Portland cement is a major contributor of global warming. The cement industry is the second largest producer of the green house gas. The total world production of cement is expected to be around $4800 \mathrm{Mt}$ by 2030 , which clearly indicates the like impact on global warming indicates. In this regard, Utilization of industrial byproducts from various industries as supplementary cementations material in concrete along with cement has been well recognized for its enhanced properties and potential to reduce environmental impacts. Self compacting Geopolymer concrete is a relatively new concrete, which can be a sustainable and Economical construction material as it is produced from combination of industrial by-products such as Fly ash and Ground Granulated Blast Furnace Slag replacing 100\% of cement in concrete. Self compacting Geopolymer concrete is a special type of concrete which can be placed and consolidated under its own weight without any vibration and which at the same time is cohesive enough to be handled without segregation or bleeding. The self compacting geopolymer concrete such as filing ability passing ability and segregation resistance are estimated by using slump flow, V-Funnel, L-Box and J-ring test method for fresh state concrete. Hence Selfcompacting Geopolymer concrete is the sustainable construction material in the modern world by solving current issues of pollution.
\end{abstract}

Keywords: Self Compacting Geopolymer Concrete (SCGPC), Fly Ash(FA), Ground Granulated Blast Furnace Slag(GGBS), Rice Husk Ash (RHA), Nano-Silica(NS), Steel Fiber(SF), alkaline solution

\section{INTRODUCTION}

Concrete is the most commonly used structural material due to the availability of raw materials and ease of shaping. [1-10]. The main binding ingredient of concrete that is ordinary Portland cement is a major contributor of global warming. [1-10]. The total world production of cement is expected to be around 4800 Mt by 2030, which clearly indicates the like impact on global warming indicate.[2]. Therefore, the impacts of $\mathrm{CO} 2$ emission on the environment and the high amount of required energy are significant issues for both cement industry and future of mankind [1-10]. Self-compacting Geopolymer concrete is an innovative method and improved way of concreting operation that does not require vibration for placing it and is produced by complete elimination of ordinary Portland cement [1-10]. Self-compacting Geopolymer concrete is an innovative binder material and is produced by totally replacing the Cement. [1-10]. Selfcompacting Geopolymer concrete is produced by activating different alumino-silicate based waste 
materials with highly alkaline solution [4]. The development of Super Plasticizer led to a better control of fresh concrete properties by making the concrete self compactable [5]. Self compacting geopolymer concrete is completely elimination of vibration and allows the concrete to flow through congested reinforcement under its own weight alone, filling the formwork without segregation of its constituent materials, Such concrete needs a high slump [1-10]. The problem with the self-compacting concrete is that it has little cracking resistance, low tensile strength, and limited ductility. Although, these curbs can be eliminated by the addition of steel fibers [1],[8]. The combined utilization of nano silica and steel fibre significantly improved the flexural strength and fracture performance [1]. Curing of freshly prepared Self-compacting Geopolymer concrete is the most crucial aspect and plays an important role in the geopolymerisation process [4]. Proper curing of concrete has a positive effect on the final properties of the Self-compacting Geopolymer concrete. Curing of Self-compacting Geopolymer concrete is carried out at elevated temperatures and ambient temperatures [4]. Therefore, the use of geopolymer technology not only significantly reduces the $\mathrm{CO}_{2}$ emissions by the cement industries, but also safe disposal and utilizes the industrial waste. [2],[3].

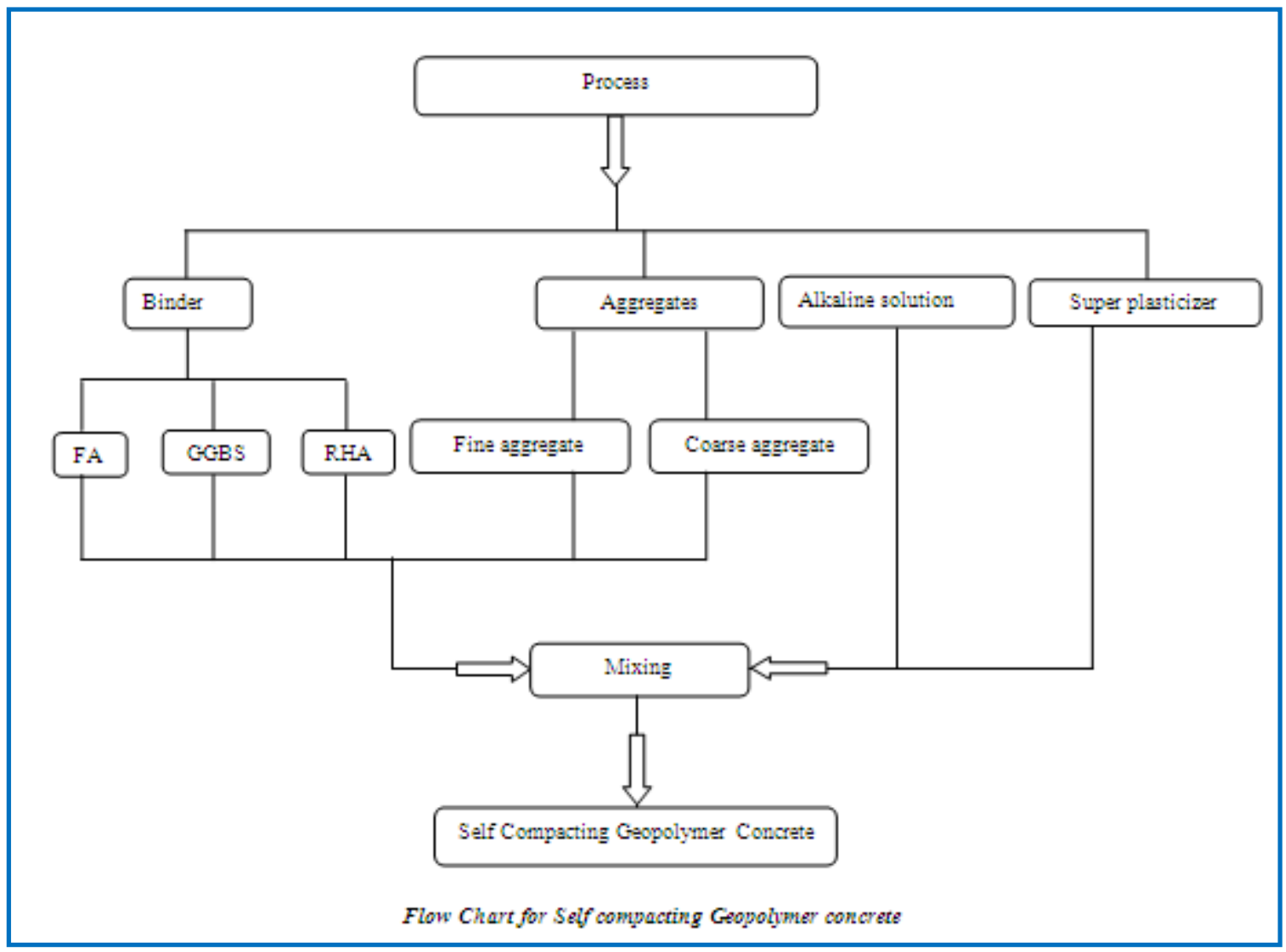

\section{LITERATURE REVIEW:}

Mehme eren gulsan et al. (2019) discussed the work on effect of nano-silica and steel fiber on the fresh and hardened state performance of self compacting geopolymer concretes. They have investigated that incorporation of nano-silica $(0 \%, 1 \%, 2 \%)$ and steel fiber $(0 \%, 0.5 \%, 1 \%)$ affected the fresh state properties. A combined utilization of them improved bond strength and flexural performance of the self compacting geopolymer concrete. In addition, the effect of nanosilica was found to be dominant on fresh state properties and compressive strength, while the effect of steel fiber was found to be superior on flexural performance and bonding strength.

Patel \& Niraj Shah.(2018) described the work on effect of temperature curing and ambient curing on mechanical properties of Self Compacting Geopolymer Concrete. They have 
the effect of percentage $(0,5,15$ and 25\%) replacement of Rice Husk Ash on the properties of Self Compacting Geopolymer Concrete. The optimum percentage replacement of Rice Husk Ash with Ground Granulated Blast Furnace Slag is 5\% at ambient curing and $15 \%$ at $70{ }^{\circ} \mathrm{C}$ temperature curing. The higher strength is obtained at $70{ }^{\circ} \mathrm{C}$ temperature curing than at ambient curing.

Fareed Ahmed et al (2011) have studied the compressive strength and workability characteristics of low-calcium fly ash based self compacting geopolymer concrete. They have studied effect of extra water, curing time and curing temperature of self compacting geopolymer concrete. The addition of extra water improved the workability characteristics of concrete mixtures. Concrete specimens cured at $70^{\circ} \mathrm{C}$ produced the highest compressive strength as compared to specimens cured at $60^{\circ} \mathrm{C}, 80^{\circ} \mathrm{C}$ and $90^{\circ} \mathrm{C}$.

Fareed Ahmed Memon et al (2011) investigated the effect of curing conditions on the compressive strength of self-compacting geopolymer concrete. The experiments were conducted by varying the curing time and curing temperature in the range of $24-96$ hours and $60-90^{\circ} \mathrm{C}$ respectively. Concrete specimens cured at $70^{\circ} \mathrm{C}$ produced the highest compressive strength and increase in compressive strength with the increase in curing time.

Muhd Fadhil Nuruddin et al (2011) described the work on Effect of mix composition on workability and compressive strength of self-compacting geopolymer concrete. The premixing of alkaline solution, super plasticizer, and extra water before being added to the dry mix of concrete has successfully improved the workability and strength. In $48 \mathrm{~h}$ and $70{ }^{\circ} \mathrm{C}$ of heat curing, $12 \%$ addition of extra water to the mixture with water-to-geopolymer solids ratio of 0.33 could improve concrete compressive strength.

Prasanna Venkatesan \& Pazhani (2015) examined the strength and durability properties of Geopolymer concrete prepared using Ground Granulated Blast Furnace Slag and Black Rice Husk Ash. Black Rice Husk Ash was replaced with Ground Granulated Blast Furnace Slag at various proportions such as 10\%, 20\% and 30\%. In addition of Black Rice Husk Ash beyond 10\% had a retarding effect on the compressive strength. Although upto $20 \%$ replacement,the target compressive strength was surpassed and strength was reached at 28 days.

Patel \& Niraj Shah (2018) evaluated the effect of Fresh and Mechanical properties of Self Compacting Geopolymer Concrete. The Self-compacting Geopolymer concrete was developed using Ground Granulated Blast Furnace Slag as the primary binder and Ground Granulated Blast Furnace Slag was replaced with 5\%, 15\% and 25\% of Rice Husk Ash. Self compacting geopolymer concrete blended with 100\% Fly Ash failed to achieve the required strength at 3, 7 and 28 days at ambient temperature due to incomplete geopolymerization process without heat. The compressive strength, split tensile strength, and flexural strength of self compacting geopolymer concrete is improved up to 5\% replacement of Rice Husk Ash with compared to control mix at all ages.

Saad Al-Rawi \& Nildem Tayşia (2018) discussed the work on impact of Steel Fiber and Ground Granulated Blast Furnaces slag content on the fresh and hardened properties of fly ash based Self-Compacting Geopolymer Concrete. Two series of self-compacting geopolymer concrete were formulated with a constant binder content of $450 \mathrm{~kg} / \mathrm{m} 3$ and at an alkaline-to-binder $(\mathrm{a} / \mathrm{b})$ ratio of 0.50 . Fly ash was substituted with Ground Granulated Blast Furnace Slag with the replacement levels being $0 \%, 25 \%, 50 \%, 75 \%$, and $100 \%$ by weight in each Self-compacting Geopolymer concrete series. The increasing the amount of Ground Granulated Blast Furnace Slag on the mixes had a negative effect on the fresh properties. In addition, using of Ground Granulated Blast Furnace Slag in the mixes of SCGC significantly improved the compressive strength. 
Fareed Ahmed Memon et al (2012) investigated the effect of superplasticizer and amount of extra water on strength and workability properties of Fly ash-based Self compacting geopolymer concrete. The experiments were conducted by varying the amount of extra water (10\% to $20 \%)$ and dosage of superplasticizer (3\% to $7 \%$ ). The increase in amount of extra water and superplasticizer, the workability was improved. However, the addition of water beyond $15 \%$ resulted in bleeding, segregation and decreased the compressive strength of the concrete.

Fadhil Nuruddin et al (2011) have studied the effects of super plasticizer and molarity of sodium hydroxide alkaline solution on the workability, microstructure and compressive strength of self compacting geopolymer concrete The parameters studied were super plasticizer dosage and molarity of $\mathrm{NaOH}$ solution. An increase in strength and a decrease in workability of these concrete samples were examined with the increase in molarity of $\mathrm{NaOH}$ solution from $8 \mathrm{M}$ to $14 \mathrm{M}$. $\mathrm{NaOH}$ Concentration of $12 \mathrm{M}$ and super plasticizer dosage of $6 \%$ produced satisfactory performance.

\section{CONCLUSIONS:}

$>$ A combined utilization of nano-silica and steel fiber improved bond strength and flexural performance of the self compacting geopolymer concrete.

$>$ The higher strength is obtained at $70{ }^{\circ} \mathrm{C}$ temperature curing than at ambient curing.

$>$ The optimum percentage replacement of Rice Husk Ash with Ground Granulated Blast Furnace Slag is $5 \%$ at ambient curing and $15 \%$ at $70{ }^{\circ} \mathrm{C}$ temperature curing.

$>$ In $48 \mathrm{hr}$ and $70{ }^{\circ} \mathrm{C}$ of heat curing, $12 \%$ addition of extra water to the mixture with waterto-geopolymer solids ratio of 0.33 could improve concrete compressive strength.

$>$ The increasing the amount of Ground Granulated Blast Furnace Slag on the mixes had a negative effect on the fresh properties.

$>$ The increase in amount of extra water and super plasticizer, the workability was improved. and water beyond $15 \%$ resulted in bleeding, segregation and decreased the compressive strength of the concrete.

$>\mathrm{NaOH}$ Concentration of $12 \mathrm{M}$ and super plasticizer dosage of $6 \%$ produced satisfactory performance.

\section{REFERENCE}

1. Gülşan, M. E., Alzeebaree, R., Rasheed, A. A., Niş, A., \&amp; Kurtoğlu, A. E. (2019). "Development of fly ash/slag based self-compacting geopolymer concrete using nano-silica and steel fiber". Construction and Building Materials, vol.211, pp.271-283.

2. Patel, Y. J., \&amp; Shah, N. (2018). "Development of self-compacting geopolymer concrete as a sustainable construction material.”, Sustainable Environment Research, vol.28, pp.412421.

3. Ahmed, M. , Nuruddin, M. , Shafiq, N. (2011). 'Compressive Strength and Workability Characteristics of Low-Calcium Fly ash-based Self-Compacting Geopolymer Concrete'. World Academy of Science, Engineering and Technology, Open Science Index 50, International Journal of Civil and Environmental Engineering, vol-5 pp64 - 70.

4. Memon, F. , Nuruddin, M. , Demie, S., Shafiq, N. (2011). 'Effect of Curing Conditions on Strength of Fly ash-based Self-Compacting Geopolymer Concrete'. World Academy of Science, Engineering and Technology, Open Science Index 56, International Journal of Civil and Environmental Engineering,vol 5(8), pp 342 - 345. 
5. Muhd Fadhil Nuruddin, Samuel Demie, and Nasir Shafiq (2011), "Effect of mix composition on workability and compressive strength of self-compacting geopolymer concrete", Canadian Journal of Civil Engineering, vol- 38, pp-1196-1203.

6. R. Prasanna Venkatesan and K. C. Pazhani (2015), "Strength and Durability Properties of Geopolymer Concrete made with Ground Granulated Blast furnace Slag and Black Rice Husk Ash” KSCE Journal of Civil Engineering, vol- 20, pp-2384-2391.

7. Yamini J. Patel, Niraj Shah, (2018) "Enhancement of the properties of Ground Granulated Blast Furnace Slag based Self Compacting Geopolymer Concrete by incorporating Rice Husk Ash”, Construction and Building Materials, vol.171, pp.654-662.

8. Saad Al-Rawi and Nildem Taysia, (2018) "Performance of self-compacting geopolymer concrete with and without GGBFS and steel fiber", Advances in Concrete Construction, Vol. 6, No. 4 , pp-323-344.

9. Fareed Ahmed Memon, Muhd Fadhil Nuruddin, Samuel Demie and Nasir Shafiq, "Effect of Superplasticizer and Extra Water on Workability and Compressive Strength of SelfCompacting Geopolymer Concrete". Research Journal of Applied Sciences, Engineering and Technology, vol 4, pp 407-414.

10. Nuruddin, M. , Demie, S. , Ahmed, M. , Shafiq, N. (2011). 'Effect of Superplasticizer and $\mathrm{NaOH}$ Molarity on Workability, Compressive Strength and Microstructure Properties of SelfCompacting Geopolymer Concrete'. World Academy of Science, Engineering and Technology, Open Science Index 51, International Journal of Geological and Environmental Engineering, vol 5,pp $187-194$. 